\title{
8
}

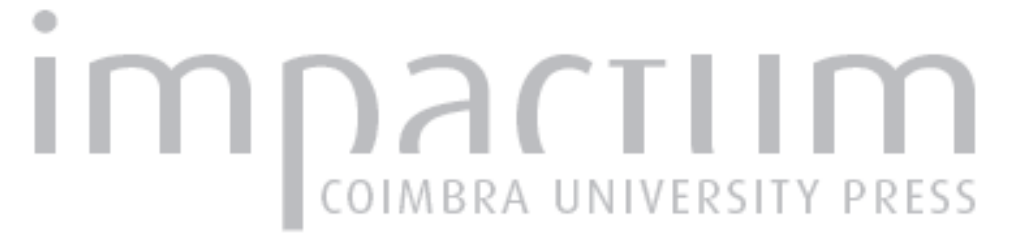

\section{O sentido da História Contemporânea}

\section{Autor(es): Marga, Andrei}

Publicado por: Imprensa da Universidade de Coimbra

URL persistente:

URl:http://hdl.handle.net/10316.2/44852

DOI:

DOI:https://doi.org/10.14195/1647-8622_18_1

Accessed : $\quad$ 26-Apr-2023 03:27:40

A navegação consulta e descarregamento dos títulos inseridos nas Bibliotecas Digitais UC Digitalis, UC Pombalina e UC Impactum, pressupõem a aceitação plena e sem reservas dos Termos e Condições de Uso destas Bibliotecas Digitais, disponíveis em https://digitalis.uc.pt/pt-pt/termos.

Conforme exposto nos referidos Termos e Condições de Uso, o descarregamento de títulos de acesso restrito requer uma licença válida de autorização devendo o utilizador aceder ao(s) documento(s) a partir de um endereço de IP da instituição detentora da supramencionada licença.

Ao utilizador é apenas permitido o descarregamento para uso pessoal, pelo que o emprego do(s) título(s) descarregado(s) para outro fim, designadamente comercial, carece de autorização do respetivo autor ou editor da obra.

Na medida em que todas as obras da UC Digitalis se encontram protegidas pelo Código do Direito de Autor e Direitos Conexos e demais legislação aplicável, toda a cópia, parcial ou total, deste documento, nos casos em que é legalmente admitida, deverá conter ou fazer-se acompanhar por este aviso.

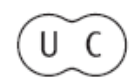




\section{ESTUDOSDOSÉCULO}

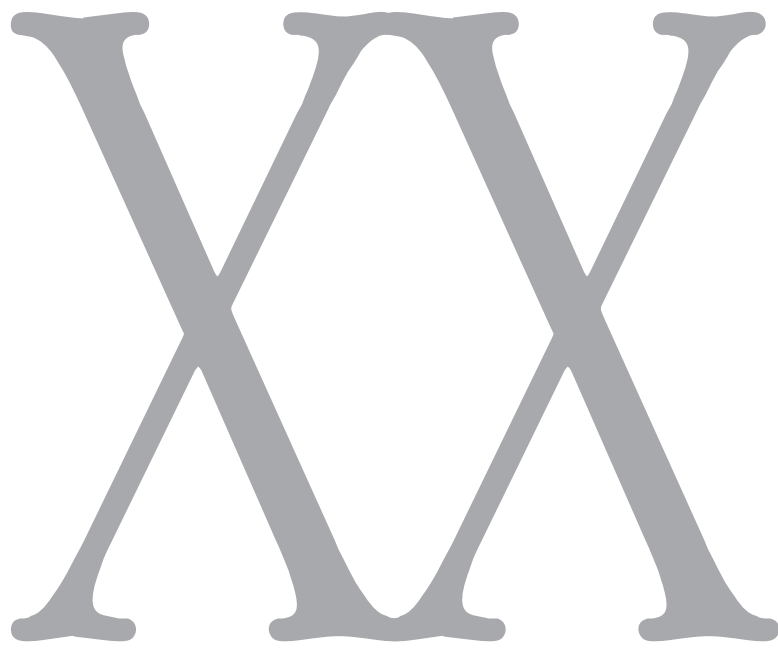

número $18 \bullet 2018$

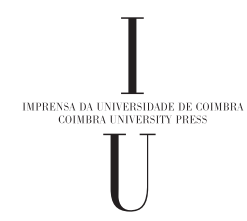




\title{
O Sentido da História Contemporânea
}

\author{
The Sense of the Our-Days History
}

Andrei Marga

Andrei Marga, Imérito académico da Universidade de Cluj-Napoca e ex-Ministro da Educação da Roménia. Email: andrei.marga@andreimarga.eu 


\section{O SENTIDO DA HISTÓRIA CONTEMPORÂNEA}

Ao longo dos tempos, diferentes autores vêm procurando uma definiçáo da sociedade. Mais espiritualista, como Hegel procurava definir, ou positiva, como Comte, entre outros autores, longa é a tentativa de antecipar o curso do tempo presente. Porém, defende-se neste texto que, nas sociedades do tempo presente, as pessoas fazem a sua história de acordo com quatro sistemas gerados pelo tempo: a economia, a política, a administraçấo e a cultura. Esta interação molda as vidas das pessoas e, consequentemente, a ordem do mundo. E é por esse motivo que entendemos que é esta visão integradora que facilita a visão e compreensáo do tempo e da História da sociedade. Para esta tentativa de compreensáo das sociedades, interessa avaliar o papel dos seus atores, sobretudo das potências mundiais que maior destaque têm (EUA, China, Rússia, Uniẫo Europeia), e que moldam, em função dos seus interesses, o mundo. Entendendo-se que a "play of the world" se vem decidindo a nível económico e militar, EUA, China e Rússia afiguram-se as três potências que moldam um novo background do mundo. Um mundo onde o confronto entre o socialismo oriental e o capitalismo liberal vem diminuindo, onde o projeto moderno de sociedade avança, perene de novos valores em competiçăo, onde as liberdades individuais e os direitos humanos parecem prevalecer num futuro próximo e o problema do desenvolvimento económico e institucional continuará a ter a primazia. Porém, há que ponderar como é que as três superpotências se văo continuar a relacionar em áreas de contacto direto, tendo em conta que váo viver num mundo que clama o multilateralismo, um mundo héctico, onde cada potência sabe que nada tem a ganhar com grandes confrontos. Nesta nova ordem mundial a Uniáo Europeia terá de se reorganizar em direção à democratização, sob pena de ver o seu futuro em perigo, e recuperar o seu status a nível mundial. Todas estas mudanças, reorganizaçóes, adaptaçóes aos tempos e às suas necessidades levam-nos a viver num mundo repleto de desenvolvimentos alternativos, com oportunidades variadas, mas profundamente incerto. Porém, sem motivos para pessimismos pois essa incerteza pode facilmente ser ultrapassada com uma avaliação aprofundada das realidades, aproveitando as possibilidades de usar a criatividade para alcançar novas ideias e novas formas de viver.

Palavras-chave: História, Sociedade, Democracia, Desenvolvimento

\section{THE SENSE OF THE OUR-DAYS HISTORY}

Several authors have, over time, searched for a definition of society. The attempt to prepare for the course of current times, in a more spiritualist way, as Hegel seeked to define, or in a positive way, as Comte did, among other authors, takes a great deal of time. This paper, however, argues that, in present-day societies, people build their history according to four systems generated by time: economy, politics, administration and cultura. This interplay shapes people's lives and, therefore, world order. It is for that reason that we believe that this integrated approach facilitates how we look at and understand time and the history of society. In trying to understand societies, it is important to assess the role of its authors, especially that of the major world powers (USA, China, Russia, European Union), that shape th world in a way that suits their interests. On the understanding that the "play of the world" is decided at economic and military level, the USA, China and Russia seem to be the three powers that give new form to the world background. A world in which Eastern socialism and liberal capitalism are declining, in which the modern society project is gaining ground, with everlasting new values in rivalry, in which individual freedoms and human rights seem to prevail in a near future and the issue of economic and institutional development will continue to take precedence. However, we need to consider how the three superpowers will work in concert on direct contact areas, bearing in mind that they will be living in a world that calls for multilateralism, a hectic world in which each power knows that there is nothing to gain if they engage in major confrontations. The European Union will have to reorganise itself in this new world towards democratisation, as otherwise its future will be in danger, and to regain its world status. All these changes, reorganisations, and adapting to new times and their needs means that we will be living in a world full of alternative developments, with varied opportunities, yet profoundly uncertain. There is no reason for pessimism, however, as that uncertainty can easily be overcome through a deeper inquiry into realities, using possibilities in the best way to use creativity in order to reach new ideas and new ways of living.

Keywords: History, Society, Democracy, Development.

\section{LE SENS DE L'HISTOIRE CONTEMPORAINE}

À travers les âges, différents auteurs ont cherché une définition de la société. Plus spiritualiste, comme Hegel cherchait à la définir, ou positive, comme Comte, entre autres auteurs, longue est la tentative d'anticiper le cours du temps présent. Nous défendons cependant dans ce texte que dans les sociétés du temps présent, les personnes créent leur histoire selon quatre systèmes générés par le temps : l'économie, la politique, l'administration et la culture. Cette interaction façonne les vies des personnes et, par conséquent, l'ordre du monde. C'est pour cette raison que nous estimons que c'est cette vision intégrative qui facilite la vision et la compréhension du temps et de l'Histoire de la société. Pour cette tentative de compréhension des sociétés, il est intéressant d'évaluer le rôle de ses acteurs, en particulier des puissances mondiales les plus importantes (USA, Chine, Russie, Union Européenne), qui façonnent le monde, en fonction de leurs intérêts. Nous considérons que le "play of the world" se décide au niveau économique et militaire, les USA, la Chine et la Russie semblent être les trois puissances qui façonnent un nouveau background du monde. Un monde où la confrontation entre le socialisme oriental et le capitalisme libéral diminue, où le projet moderne de société avance, pérenne de nouvelles valeurs en compétition, où les libertés individuelles et les droits humains semblent prévaloir dans un futur proche et le problème du développement économique et institutionnel continuera à avoir la primauté. Il faut cependant pondérer comment les trois super puissances vont continuer à être liées dans des domaines de contact direct, vu qu'elles vont vivre dans un monde qui clame le multilatéralisme, un monde hectique, où chaque puissance sait qu'elle n'a rien à gagner avec de grandes confrontations. Dans ce nouvel ordre mondial, l'Union Européenne devra se réorganiser en direction de la démocratisation, sous peine de voir son futur en danger et récupérer son statut au niveau mondial. Tous ces changements, réorganisations, adaptations aux temps et à leurs besoins nous font vivre dans un monde plein de développements alternatifs, avec des opportunités variées, mais profondément incertain. Toutefois, sans motifs de pessimisme, car cette incertitude peut facilement être dépassée grâce à une évaluation approfondie des réalités, en profitant des possibilités d'utiliser la créativité pour atteindre de nouvelles idées et de nouvelles façons de vivre.

Mots-clé: Histoire, Société, Démocratie, Développement. 
As we know, Hegel was keen in observing the changing of the world of his time. He was informed about the "American Revolution", while the "French Revolution" was happening not far from his place. He was part of a nation under construction and of a $n$ Europe under reorganization. He had knowledge about the development of modern science, of market economy and of the State based on individual rights and liberties. He was aware of the opening brought about by the research of "historical Jesus", on the background of the "eschatological Jesus". For all these reasons, Hegel saw in the identification of the sense of history the key of the understanding of the world.

The concepts of Hegel's view of history are: "subject", "freedom", "constitution", "state", "civil society", "sense", and "labor", "family (interaction)", "language (communication)", as milieus of the historical implementation of the "spirit". With a step which generated misunderstandings Hegel unified his concepts under the concept of "spirit". His thesis was that modern society represents a culmination in the progress towards the consciousness of freedom. The one who is aware of his/her freedom is free.

Today, we do not dare to follow Hegel in this respect. The motives of human actions are less spiritual, and, more than he believed, "menschlich, allzu menschlich", as Nietzsche put it. The conditioning of initiatives is new, and the results of actions are different. Therefore, it is the case to resume Hegel's interrogations and to leave aside his approach.

Many thinkers have resumed these interrogations. Consequently, we have behind us a history of the diagnoses of modern society: a society of freedom, of exploitation, of sciences, of technology, and, in recent decades, an "asymmetric society" (James S.Colleman), "a society of moral vacuum" (Giles Lipovetsky), a "cinic society" (Peter Sloterdijk), a "chaotic society" (Gianni Vattimo), a "lying society" (Wolfgang Reinhardt), an "invisible society" (Daniel Innerarity), a "risks society" (Ulrich Berger), a "turbulent society" (Alan Greenspan), an "infantile society" (Alexandra Viatteau), an "indifferent society" (Alain-Gerard Slama), a "cleptocratic society"(Sarah Chayes), and a "narcissic society"(Hans-Joachim Maaz) .

But, after Hegel, we have also a history of the attempts to anticipate the course of the present time. As we know, Auguste Comte spoke about the "positivation" of knowledge and human affairs due to the progress of experimental sciences, Marx spoke about the "transition to communism", Max Weber about the society of a "strong submission of individuals" due to the expansion of birocracy, Spengler about the "decline of the West", Dewey about the triumf of democracy, and, finally, Horkheimer and Adorno spoke about the regression of modern society under the "domination of blind nature".

In a new situation, my thesis is different. If it is to formulate the idea directly, I would say that, in the societies of the late modernity, people make their history, and they make it within four systems generated in time. I have in mind the economy, where I also include science and technology, politics, where I place the organizing values and the army, the administration, where I include the system of justice, culture, where I also place education and reflexivity. The life of the people of our time passes through these dependencies.

This being the case, to the simple question which many people ask these days, namely, "where to is the world going?" or "what will it be?", the answer most able of factual confirmation is that the world goes in a direction generated by the 
interaction of the four systems. My thesis is that the sense of present history comes from this interaction, that it inevitably shapes people's lives, and that world order also results from this interaction. Interactionism is far better than its opposing approaches. It is about the mindset which subordinates history to some metaphysical scenarios (the irrepressible advance towards something, the ubiquity of the good or evil, the triumph of some "races" or religions), about imagining a subject of history in large format (a dominant power, an occult force, a fatal coalition, a social group), or, finally, about the mere exaltation of happening in history.

At this point, I immediately add two observations.

You can't isolate a system to be all-explicative. It is an error of the followers of the German classical philosophy, tempted by the latter's idea to unify all experiences, to take a "factor" (for instance, the economy, with some partisans of Karl Marx, or culture, with some followers of Max Weber) as an overall determinant ${ }^{1}$. The interactionist approach leaves behind the difficulties of monism, without falling into Foucault's pessimism, or Luhmann's elevated bureaucratism. Foucault sees structures, but not people, while Luhmann only recognizes functional systems that swallow any initiative.

Sense is not to be approached as a one-sided, singular issue, but as a compound of questions, such as: How come I ended up in this situation? Are we confirmed or are we mistaken? Is our life better off or is it endangered? Are we only surrounded by facts, or also by something that integrates facts and makes them coherent? Has the totality of facts any relevance? How are objects, values and actions formed? We have truths, but are they useful, and if they are, in what way? We use values, but to what purpose? From the countless questions that may be formulated, how to distinguish the useful ones? We know the history of the present, but where does it take us? Are we confident that what we see is really happening, or are we mistaken? What is the meaning of life? Is there a purpose in it? What is the meaning of people's life? What is the sense of my life? What is the sense of the world?

All these questions may come down to two questions, which make up the case of sense as such: a question of direction - what societies are we heading to? and a question of significance - how do they impact our life? Therefore, sense it is a composed question.

I will argue my thesis by appealing to historical, economic, sociological, geopolitical facts and analyses. My approach is a philosophical one, but it is based on arguments coming from recent social sciences.

What will be the impact of the four systems on the sense of current history? Here is a synthetic picture of the direction we are taking.

In economy, we are at the dawn of neoliberalism, but the new solution of " the naturalization of economy" takes time to be articulated. The reaction of the most

\footnotetext{
${ }^{1}$ Some contemporary approaches are also simplifying too much the things when considering that "language created the tribes, writing the advanced ancient culture, printing press brought about modern society, and the computer shaped the society to follow" (BAECKER, Dirk - Studien zur nächsten Gesellschaft. Frankfurt am Main: Suhrkamp, 2007. p. 7).
} 
important economists ${ }^{2}$ is symptomatic. Globality is the framework of the present time, globalism remains an ideology, while globalization, as it has been conceived starting with the nineties, needs corrections. The most powerful economies in the world operate them, strengthening the role of the respective State.

The result is that post-globalization is taking shape as a concrete possibility ${ }^{3}$.The causes are, in fact, four.

Advanced societies already face difficulties, which globalization does not resolve, with the distribution of burdens and benefits, the access to decisions, the risk control, and with motivating citizens. Thus, so far, globalization has swept only some of the fields, in varying degrees, so that we can talk about globalization in scientific research, economy, communications, security, but, in others, we dare only talk of internationalization, or even less. On the other hand, globalization extends to a maximum the market on which the products are exchanged, but it cannot prevent the enlarging of other spheres (such as personal or institutional autonomy, community life, private life, inner life), and it even directly or indirectly encourages the extension of needs, the looking for alternative way of life, and sense. It becomes more and more clear - as the research into history has proved ${ }^{4}$ that the globalizing structure of the present world has roots in the dynamics of some nations and what passed as universality was mainly their experience.

The analysis of the sources of change brings about research into the future. In the context of globalization, one appeals to the past in order to serve the present, and research into the future is considered irrelevant since it cannot be exchanged on the market. This exploration requires interrogations and conceptualizations that go beyond the rather functionalistic approaches

At stake is not marketization, but the illusion that it is the only mechanism of socialization. The social State is not the source of difficulties, but its distortion on the "right", by those who want to annihilate it, or on the "left", by those who do not refine it $t^{5}$. Neither the "invading State" of bureaucratic socialism, nor the "frail State" of classical liberalism are the solutions ${ }^{6}$, and a profound reconsideration is indispensable. The self-assuming of the States seems to become the new solution.

The sciences continue their evolution within which discoveries are made, drawn by the objective of their application. The geography of the cultivation of science

\footnotetext{
${ }^{2}$ KRUGMAN, Paul - The Return of Depression Economics and the Crisis of 2008. New York; London: W.W.Norton \& Company, 2009; STIGLITZ, Joseph E.- The Great Divide. New York: Penguin, 2015; ATKINSON, Anthony B. - Inequality. What can be done?. Harvard University Press, 2015; GALBRAITH, James K. - Wachstum neu Denken. Was die Wirtschaft aus der Krise lernen muss?, Zürich: Rotpunkt Verlag: 2016; PIKETTY, Thomas - Chronicles. On our troubled times. New York: Viking, 2016.

${ }^{3}$ For details, see MARGA, Andrei - Metanarativii actuali. Modernizare, dezvoltare, globalizare. Cluj-Napoca: Gând Transilvan, 2015., p.131-182

${ }^{4}$ BERMAN, Harold - Recht und Rechtsrevolution: die Bildung der westlichen Rechtstradition, Frankfurt am Main: Suhrkamp, 1991; SASSEN, Saskia - Territory - Authority - Rights. From Medieval to Global Assemblages. Princeton University Press, 2006

${ }^{5}$ MARX, Reinhardt Cardinal - Das Kapital. Ein Plädoyer für den Menschen. München: Knaur, 2010. pp. $159-187$.

${ }^{6}$ STIGLITZ, Joseph - La globalizzazione e suoi oppositori. Torino: Einaudi, 2002. p.224.
} 
expanded ${ }^{7}$, but it is still unclear how the system of sciences looks like. With the unified theory of nature, in the form of the transcendentalist hypothesis ${ }^{8}$, the series of debates on physics as the unifier of knowledge have been closed, at least at present.

There are, however, deep vision changes due to sciences. Let me mention a few of them. The theory of the auto-poetic systems showed how cognition creates its elements prior to its contact with the environment ${ }^{9}$. The theory of language use has revealed that you cannot designate objects without identifying them (Peter Strawson), that we cannot assign logical predicates without including ourselves in the assignment (Shoemaker), and that we can't prove something before understanding it (Noszik). After Einstein wanted to reduce time to space, today it is accepted that time is something autonomous and there are discussions about the historicity of the laws of nature ${ }^{10}$. Peirce's view of uniformities as resulting from evolution enters the scene. Joseph Ratzinger reaffirmed it when he interpreted "the miracles of Jesus" within the historical character of the laws of nature ${ }^{11}$. The limitations of life (evil, starvation, suffering, sickness and death) come into the proscenium and the writing of history as it was, less about accomplishments, and more about failures, begins ${ }^{12}$. The application of data processing in medicine encouraged joined efforts to decipher the genetic code and epigenetics, and the "the packing of genes" becomes the key idea in therapies. You can't go beyond any limit in life, but life of many people can be prolonged ${ }^{13}$. After the region in the brain which becomes active when a person attaches herself to others was located, and after oxytocin and the "instinct" of altruism were identified ${ }^{14}$, Darwin's paradigm of the survival of the fittest entered its final phase. Empathy returned among the notions of epistemology ${ }^{15}$.

In politics, we are in an extended-society - the "world society" (Luhmann) being already a reality. Some believe that in its terms, people should do what they are told to do from a Center! It has become clear, however, that the national framework is among the conditions for the possibility of democracy ${ }^{16}$. "Political correctness" is shared by many people, but its criticism has started as well. Cleptocracy has been extended, in

\footnotetext{
${ }^{7}$ ANGANG, Hu - China in 2020. A New Type of Superpower. Washington DC: Brookings Institution Press, 2011. p. 95-120.

${ }^{8}$ WEIZSÄCKER, Carl von - Die Einheit der Natur. München: Carl Hanser, 1971.

${ }^{9}$ MATURANA, Humberto R. - Kognition. In SCHMIDT, Siegfried J. - Der Diskurs des Radikalen Konstructivismus. Frankfurt am Main: Suhrkamp, 1987. p.89-118.

${ }^{10}$ SMOLIN, Lee - Time Reborn. From the Crisis in Physics to the Future of the Universe. Harcourt: Houghton Mifflin, 2013. Part I, 5.

${ }^{11}$ RATZINGER, Joseph / Benedikt XVII - Jesus von Nazareth. Herder, Freiburg, Basel, Wien, Band 1, 2007. p. 15-22.

${ }^{12}$ NEIMAN, Susan - Das Böse denken? Eine andere Geschichte der Philosophie. Frankfurt am Main: Suhrkamp, 2006.

${ }^{13}$ HUBER, Johannes - Länger leben.Medizinische Perspektiven und ihre Bedeutung für Gesellschaft. In LIESSMANN, Konrad Paul - Ruhm, Tod und Unsterblichkeit. Über der Umgang mit der Endlichkeit. Wien: Zsolnay, 2004.

${ }^{14}$ GILBERT, Paul - The Compassionate Mind. A New Approach to Life's Challenges. New York: New Harbinger, 2009.

15 TROUT, J.D. - Why Empathy Matters. The Science and Psychology of Better Judgement. New York: Penguin, 2008. p. 21-55.

${ }^{16}$ MANNENT, Pierre- La raison des nations. Reflexions sut la démocratie en Europe. Paris: Gallimard, 2006.
} 
and out, and it requires solutions ${ }^{17}$. Diversification returned on the map of democracy: the "liberal democracy" of America inspires most of the world, but the European "post-democracy" 18 , the "oriented democracy" in Russia, and the "democracy in specific characteristics" of China are also present. In all these, the question of meritocracy arises. Steps towards democracy are taken, but the distinction between the dismantling of authoritarianism and the construction of democracy are rarely taken ${ }^{19}$. Military capability is increasing, but it matters less who is the most advanced, than the force of destruction is huge on almost all sides. Nuclear proliferation has not been stopped.

In administration, States, while observing classical jurisdiction (Hans Kelsen), tend to pass decisions from democratic mandate to the attributes of the leaders. Decisionism (Carl Schmitt) has spread. More recently, it claims itself from "complexity", but the issue of legitimation, however, has come to the forefront. The applications of electronics and computer science have made private life vulnerable. It can no longer preserve intimacy, so that it depends on the competition ${ }^{20}$ between technology, which expands the surveillance of the persons, and legislation - the last bastion of privacy defense. Coordination in the world system needs new negotiations. A new migration of peoples takes place and jihadists of various causes are hiding in its waves.

In culture, the comprehensive concept of culture is gaining recognition: culture includes literature and art, but also advanced technology, the system of law and justice, public debate, advanced reflexivity, religion and philosophy. Some countries impose the condition of language to immigrants and are reluctant towards multiculturalism as civic multilingualism, but multiculturalism as a strategic solution remains, however, in force. Not only that some countries, by force of historical facts, accept religious and cultural diversification, but the coming on the stage of China with its most spoken language, longest history, extensive presence in the world and impressive innovation, has changed the picture.

We are witnessing the decline of professional training in Europe ${ }^{21}$. Although projects like PISA and Bologna could be useful, their application has entered the narrow frames of neoliberalism, which has reduced their relevance ${ }^{22}$. Not just the need for religion, but also the partaking of religion has known a recrudesce which remains ambiguous so long as terrorism accompanies it. The assuming of the "historical Jesus" beside the "eschatological Jesus" has made steps forward, but the issues advanced in The Declaration of Seelisberg (1947) and in Nostra Etate (1965) still need some changes in the practical live of the communities. The reconsideration of the role of the church, and of the

\footnotetext{
${ }^{17}$ CHAYES, Sarah - Thieves of State. Why Corruption Threatens Global Security. New York, London: W.W.Norton \& Company, 2015.

${ }^{18} \mathrm{CROUCH}$, Colin - Postdemokratie. Frankfurt am Main: Suhrkamp, 2003. p. 30.

${ }^{19}$ O'DONNELL, Guillermo; SCHMITTER, Philippe C. - Transitions from Authoritarian Rule. Tentative Conclusions about Uncertain Democracies. Baltimore: The John Hopkins University Press, 1986.

${ }^{20}$ SCHMIDT, Eric; COHEN, Jarel - The New Digital Era. Reshaping the Future of People, Nations and Business. London: John Murray, 2014.

${ }^{21}$ GREENSPAN, Alan - L' Era de la turbolenza. Milano: Sperling \& Kupfer, 2005. p.315-319.

${ }^{22}$ LIESSMANN, Konrad Paul - Theorie der Unbildung. Die Irrtümer der Wissensgesellschaft. München, Zürich: Piper, 2008; MÜNCH, Richard - Globale Eliten, locale Authoritäten. Frankfurt am Main: Suhrkamp, 2009.
} 
specific role of the priest are now on the agenda, but against the background of the affirmation of the salvific mission of Christianity. The prospect of the institutionalization of Christianity in China ${ }^{23}$ entails consequences around the world.

We can predict that economy will drive political decisions, science will have an increasing impact, military power will have a big share, democracy will hardly defend itself in widespread conflicts, and that the "cultural turn" of the civilized world will continue. Each of the systems will play an irreducible role. As a result, a keen description of the coming world results in a variable geometry, with continuous displacements of planes, in which the problems of a system will often take the cover of another system. At one time or another, one or the other of the systems will play the stronger role, so that generalization is less probable.

\section{II}

There will be a variable geometry dependent on identifiable actors. The club of the world players will increase since the reaffirmation of the nations is just at the beginning. It is enough to see the rapid expansion of the emerging powers and the enlarging of "nuclear powers club".

But the world in which we have entered is a world where superpowers have the greatest impact on events. Their actions will influence the evolution of the societies. What is the picture of these superpowers? What is the order resulting from their interference?

From an economic point of view, the United States will continue to be the technological avant-garde with the most significant self-renewal, and the most sought-after partner. America is based on organizational principles that sustain dynamics in society - principles that combine individualism with democracy in a way that, as we know from Max Weber, cannot be copied. America has accumulations which grant it primacy. Universities play a leading role ${ }^{24}$ to ensure the unusual vigor of society. The United States remain the field of high return on investment, which is most attractive for venture capital.

China is not only the country that has most changed itself, but also the country that has most changed the world. In 2009, it became the biggest exporter. However, China needs raw materials and energy beyond what it holds. It needs markets, after it returned to the position of the largest manufacturer in the world. The presence of investment, personnel, Chinese development initiatives in the countries of Africa are surpassed only by America, while, in Europe and in the two Americas, the capital and Chinese banks are constantly getting stronger. China struggles with the improvement of the indicator of per capita production and, of course, with the increase in technology and poverty reduction. It is about to consolidate its internal market, by increasing

\footnotetext{
${ }^{23}$ AIKMAN, David - Jesus in Beijing. How Christianity Is Transforming China and Changing the Global Balance of Power. Washington DC: Regnery Publishing, 2006. p. 282-294; FERGUSSON, Nial - Civilization. The West and the Rest. Allen Lane, 2011. p. 277-288; MARGA, Andrei - Ascensiunea globală a Chinei. București: Niculescu, 2015.

${ }^{24}$ ZACHARIA, Fareed - The Post-American World. W.W.Norton \& Company, 2012. p. 207; see also NYE, Joseph S. - Is the American Century Over?. Cambridge: Polity Press, 2015.
} 
its consumption, which will have repercussions across the globe. The fact that every fifth man on Earth is Chinese, and that a population increasingly prepared acts for modernization has enormous implications for the future world.

The US cannot be matched as an economic power in the years to come, but at present, in terms of volume of production, they are second to China, both detaching themselves as economic superpowers. Employment of incomparable dimensions - 780 million workers in China, compared to 448 million in India, 157 million in the U.S., 111 million in Indonesia - confer the great country of the East tremendous prospects in the movement of the world economy.

The two economic superpowers are joined by the European Union, as the largest exporter of the world. The case of Greece has signaled, however, that the disparities of development in the United Europe require solutions which the present neoliberalism cannot offer. The East has remained an unsolved problem, and emigration from Romania, Bulgaria and other countries is not the proper solution. It has become clear $^{25}$ that the application of the "shock therapy" without investments is not able to give results in real time. In Central Europe, Hungary and Poland are seeking, on their own, ways to acquire energy and financing.

Today's most spectacular developments in education take place in China. The United States still have the most powerful system - at least in terms of performance in scientific research and technological renewal, specializations, and production yield. China has passed amazingly fast from a country hit by illiteracy, to a country which has the school drop-out percentage lower than some European countries. In 2015, against the background of an opening without refrain towards modern educational solutions, this country registered over 33 million university students, more than 22 million vocational school students, 290 million people in continuing education, and a population of 145 million graduates. The prospect of becoming "the World's Leading Human Ressources Power" ${ }^{26}$ is close. Europe still has to get rid of the erroneous neoliberal application the PISA and Bologna programmes ${ }^{27}$ in order to be able to resume its education strength, which once conferred it a leading place in the world.

The same repositioning is going on in science and technology. In 2009, USA (with 1.5 million) and China (with 1.9 million), had over a million researchers involved in Research and Development. There were 20 million graduates in science and technology at university level in China, and 17 million in the USA. China comes up and applies the most advantageous methods for the measurement of labor. In research output, in 2008, China passed ahead of England, Germany and Japan, becoming the second force in the world. The distance to the U.S. diminished from 9.5 times in 2000, to 4,3 in 2007. In 2007, China surpassed Japan in the number of computers in operation and reduced to 3.2 times the distance to the USA. With 300 million people connected to the Internet, China occupies the first place in the world.

\footnotetext{
${ }^{25}$ SACHS, Jeffrey D. - The fine della poverta. Comme i paesi potrebbero defitivamente eliminare miseria dal pianetta. Milano: Mondadori, 2005. p. 140-157.

${ }^{26}$ ANGANG, Hu - China in 2020. A New Type of Superpower. 2011, pp. 82-94.

${ }^{27}$ NIDA-RÜMELIN, Julian; ZIERER, Klaus - Auf dem Weg in eine neue deutsche Bildungskatastrophe. Zwölf unangenehme Wahrheiten. Freiburg im Breisgau: Herder, 2015, pp. 93-154.
} 
From the military standpoint, the United States and Russia detach themselves as nuclear superpowers, with the incomparable capacity for intervention and deterrence. China quickly advances through the articulation of the naval fleet (with aircraft carriers and nuclear submarines), of aviation (including spacecraft and satellites) and the most refined weapons of action at a distance. France and the United Kingdom remain nuclear powers which justify claims to a global role.

A problem arising is the change in the conduct of war. With the spread of terrorism, you may have the most sophisticated weapons without being able to annihilate the attackers, who infiltrate urban crowds, banking and information networks, and, on top of that, are ready to die in a destructive blast. The cyberwar is already a reality.

Consequently, fast-growing controls on bank flows, communication networks, and mobilities have developed. Under these circumstances, secret services have gained an ascendant in today's societies. In this respect, the superpowers have an advance, but Germany, Israel, United Kingdom, France, have also a caliber.

From a political standpoint, the US will continue to exert the greatest influence in the world. This position is ensured by the soundness of their democratic institutions, the participation in the conclusion of the world wars and other conflicts around the globe, their economic, military and cultural preeminence, and their capacity of self-renewal.

China, however, with the program of institutional changes, attracts countries that have embarked upon their own development. Its opening towards the world, its learning from the best experiences, the size of its work force, the contacts with different countries (500 million Chinese tourists visiting other countries in four years), the mastering of foreign languages (French analyses say that 29\% of the Chinese speak another language) ensures the propulsion of this most populated country. In addition, the diplomacy of "harmony" represents a constant attraction.

With its resources and tradition, Russia has established relations around the globe and is seeking to attract through a diplomacy of "equilibrium". Other countries attract through high-quality thinking, through technology and quality of life, more recently, through an open attitude towards the immigrants (Germany), intellectual traditions (France), practical diplomacy (England), know-how (Israel), or through natural resources, even if they do not display extensive ambitions.

A strong economy is not possible without market as regulator, market economy is not possible without democracy, democracy does not necessarily result from market economy. Democratization is not optional. Western States operate with liberal democracy and a strong nation-State. Many countries operate with liberal democracy, but in some cases States remain fragile.

At present, Russia has adopted "the third way" between the Russian tradition, authoritarianism and democratization ${ }^{28}$. After the difficult years that have preceded the formation of the Russian Federation, the reintegration of its society around the ideas of "national unity, patriotism and strong central Government" and, with it, the

\footnotetext{
${ }^{28}$ SAKWA, Richard - Putin. Russia's Choice. London: Routledge, 2008. Part 3.
} 
articulation of a strong state power, which rejects "dictatorship" and "totalitarianism", but wants to place itself on top of democracy, come back in the foreground ${ }^{29}$.

China preserves the idea of "democracy with Chinese characteristics", but believes that "democracy cannot be dissociated from elections and competition". Consultative democracy is of course very important, but consultation does not exclude not elections ${ }^{30}$. China programmatically embraces the "balance" between "individual rights and public rights" as part of a "democratic development".

The world's superpowers extensively claim to be based on democracy. However, today, the differentiation of democracies is obvious, and it is dealt with in a more or less polemical way in international relations. At present, democracy should exhibit some minimum criteria, so that its former relativization is not going to be accepted anymore $^{31}$.

Three issues do not allow relativization. The first is that not every democracy is compatible with development. Joseph Stiglitz extensively argued that, under the conditions of globalization, neither the "debilitated" governments, nor the "invadante" ones give results. The second issue is that governance and government are not interchangeable. If it is not circumscribed by a democratic government, governance could become able to dissolve democracy ${ }^{32}$. And the third issue is that liberal democracy itself gives results only if it incorporates meritocracy. As seen today, staff selected in an improvised or corrupt way, or through accidents of history, finally weakens the most liberal democracy, while oligarchic democracies may be saved by carefully chosen decision-makers.

Those who oppose democracy or are using it as an instrument are not negligible, neither in number, nor in force. History gives us enough examples to say that democracy does not last forever, that democracy supposes democrats to sustain it. It is triumphant when it is really practiced, not just as a technique of periodic selection representatives, but, as John Dewey said ${ }^{33}$, as a "form of life."

The Euro-American culture further uses the advantages which have brought it to the center of human culture - the pursuit of "good life", truth verified in experience, social life based on universal norms, communication, and performance. But, for the first time in history, the Euro-American culture encounters a culture - the Chinese culture - of an unusual magnitude and competitive achievements.

The Chinese culture today is spread on all continents, inter alia, by a network of institutions, the Confucius Institutes, that does not have an equivalent in terms of scale and organization. In 2015, the Confucius Institutes Hanban would operate in 475 Confucius Institutes around the globe, 851 Confucius classes in 126 countries.

${ }^{29}$ MYERS, Steven Lee - Putin - der neue Tsar. Seine Politik - Sein Russland. Zürich: Orel Füssli, 2016. p. 232, 424; NALBANDOV, Robert-Russian Foreign Policy under Putin. Not by Bread Alone. Potomac Books, The University of Nebraska Press, 2016.

${ }^{30}$ KEPING, Yu - How to Achieve Orderly Democracy, in “Beijing News”. (July 13, 2014).

${ }^{31}$ BOBBIO, Norberto - Il futuro della democrazia. Torino: Einaudi, 1995.

${ }^{32}$ MARGA, Andrei - Guvernanță și guvernare. Un viraj al democrației?. București: Compania, 2013. p.62-121.

${ }^{33}$ DEWEY, John - The Ethic of Democracy. 1898. In DEWEY, John - The Early Works 1882-1898. Illinois University Press, 1969. 
Being the result of a long history (comparable only to the Jewish culture, among the cultures of the peoples that have come down to our times), the Chinese culture penetrates general education in more and more places in the world. Its tutelage figure, Confucius, left nothing less than Socrates, even if he had spoken before the author of the maieutic. The impact of his ideas on his people and humanity stands beside that of Moses or Cicero on world history.

The European Union holds a set of values that make its specific and are traditionally most attractive. Modern science, the evaluation of activities and institutions in terms of efficiency, liberty conceived as autonomy, the inalienable rights of the person, political will located in deliberative democracy, the recognition of an immanent meaning of life are still landmarks of humanity. But the "crisis of immigrants", with its tragedies, has shown again that things are not in order. The issue is not migration or the fact that Europe is concerned about its own defense, but the amazing lack of wise co-ordination and corresponding administrative decisions in the European Union.

The $19^{\text {th }}$ century split between the human rights defenders and the promotors of change in society has not passed away. Human rights have become, however, juridically speaking, the foundation of today's democracies, and changes in society tend to incorporate them.

A discussion has been started in the United States and Germany regarding the reinstatement of democracy in conjunction with meritocracy. It was argued ${ }^{34}$ that the failure of the idea of the general triumph of liberal democracy and of Francis Fukuyama's prediction of the "end of history", the meritocratic form of leadership will have to be seriously taken into consideration. "Meritocratic" leadership, i.e., leadership recruited according to competence and political decision capacity has been counterbalanced by a leadership resulting from electoral campaign budgets and marketization ${ }^{35}$. This is another step towards concluding that democracy has to revise its strategic capability and capacity for systematic learning ${ }^{36}$ as a condition of its strenght.

At present, the United Europe is facing an unexpected problem of recognition. American analysts point to the fact that the institutional accomplishment of Europe is too slow ${ }^{37}$. From the standpoint of China, Germany, France, Great Britain, and Italy are more visible than the European Union ${ }^{38}$. Israel signals the fact that Europe has not yet solved its problems with the past ${ }^{39}$ and it is therefore hampered from the inside.

This is, in short, the superpowers' "play", performed in tandem, a triangle or any other geometric figure. The intuition of Metternich regarding the configuration of the world based on the relation between the larger powers returned to date. Bismarck

\footnotetext{
${ }^{34}$ HALPER, Stefan - The Beijing Consensus. How China's Authoritarian Model Will Dominate the Twenty-First Century. New York: Basic Books, 2010.

${ }^{35}$ BELL, Daniel A. - China and Democracy. What America's flawed democracy could learn from China's one-party rule, in "Christian Science Monitor". (December, 24, 2012).

${ }^{36}$ WILLKE, Helmut - Demokratie in Zeiten der Konfusion. Frankfurt am Main: Suhrkamp, 2014, pp. $95-98$.

${ }^{37}$ MORGAN, Glyn - The Idea of an European Super State: Public Justification and European Integration. Princeton University Press. 2007. p. 199-205.

${ }^{38}$ SUI, Yu - China in a Changing World. Beijing: Foreign Languages Press, 2015.

${ }^{39}$ YOVEL, Yirmiahu - Dark Ridle: Hegel, Nietzsche and the Jews. Cambridge: Polity, 1996.
} 
is still inspiring with his saying that when there are five powers on stage, it is but rational to be in good terms with at least two of them.

Since, at this point, the "play of the world" is decided at the economic and military level, there is, for the time being, a comeback to the world in three (theorized by Helmut Schmidt or Henry Kissinger). When it comes to strategical-military arrangements which directly affect the global agenda, the U.S., China and Russia are now in the front, Germany, Great Britain or France will tilt the balance of the solutions, while Poland, Italy, Turkey, from our part of the world, cannot be ignored.

\section{III}

The world, however - in three or three plus - is made against a changed background. Three new characteristics are involved.

The first characteristic is about the wearing out of the confrontation between oriental socialism and liberal capitalism, after more than a hundred years. Social solutions are no longer the preserve of the East and the socialists, and private initiative and market economy did not remain only in the West, with the Liberals and Christian-Democrats. Asian countries have successfully embraced the market economy and more and more clearly the rule of law.

The second characteristic is that the modern project of society advances in history - despite the action of national-socialism and its satellites. Private property, market economy, rule of law, individual rights, pluralism, democracy, information, communication, and quality of life prove to be in far more complicated connections than considered in the 20 th and 21 th centuries. And it is around their junction that a new competition of values will be launched.

The third characteristic is that the individual liberties and human rights will prevail in the years to come, and the problem of economic and institutional development will retain primacy. There will be differences of approach - China, for example, pleads to consider together, according to UNO proclamations, the political, economic and social rights ${ }^{40}$ - but each of them will be claimed from different approaches.

Terrorism will put to the test the soundness of open societies. It will take advantage of the opportunities of the "digital age" and will try to attract the adventurers and unsatisfied of various places, as the Islamic State has already proved. The civilized world has at hand, however, the possibility to counter the dangers through an explicit solidarity between the U.S., China, Russia, European Union and different countries. The importance of "responsibility" as legal and moral value will increase. "Blocks" are no longer considered to be a condition of international solidarity.

\section{IV}

How will the three superpowers relate to each other in areas of direct contact? How will they relate in the global space?

${ }^{40}$ JIE, Liu - Human Rights. China's Road. Beijing: China International Press, 2014. 
The file of the border report has changed. In 1973, the United States could take advantage of China's will to affirm itself, in the context of the confrontation of ideological ambitions between the Soviet Union (Khrushchev) and China (Mao Zedong), and of the divergences at the border. Now the landscape looks different. The Chinese say that the treaty in force between the two countries ensures "good relations between neighbors, friendship and cooperation", and it favors "model relations for great powers" ${ }^{41}$. In contrast, in the South China Sea, the US and China have a problem that the American diplomacy did not surpass: China wants to recover some islands, and the US is linked by treaty with the countries in the region that fear China's breadth. On the other hand, Russia sees the Eastward expansion of NATO as an entry on its own security belt, while China considers it to be a manifestation of what it criticizes - "hegemony" and "unilateralism".

From such disagreements, various scenarios may arise for the years to come. More likely, despite occasional divergencies, the negotiation scenario seems to be more convenient. China needs calm on the outside for its high economic growth and institutional development. Russia needs time to modernize its industry and to restore its former superpower status. The US will avoid international coalitions that could favor, even indirectly, terrorism and other threats to order. Therefore, even if the one to one contact may vary in time, it will not fundamentally affect the relations between these superpowers.

Superpowers must deal with the present order in the world. The US defends a "world order" stated in the treaties, but would want Russia to accept it, and China to back it. Russia does not accept the existing order, considering it does not answer its interests, but Russia is not in the position to force a decision of change, and is persistently striving for direct discussions with the US. Thus far, China has not accepted the invitation to assume responsibility for a "world order" to which it has not contributed, but it is interested in the creation of a "new world order". China has separated foreign policy from the struggle of visions and rejects "the unipolar world". However, it accepts the idea that, without the support of the US, a "new world order" is not possible.

The superpower capable to mobilize allies will prevail on the global arena. Besides the countries already mentioned, Japan, India, Turkey, Brazil, South Africa, Poland regain or gain international status and their position will weigh in the balance of powers. To these are added Kazakhstan, Azerbaijan, Egypt, Iran, Saudi Arabia and Nigeria, which will influence regional events.

There will not be sustainable one-sided victories when deciding the order of the world. As a matter of fact, population growth everywhere has brought new generations on stage and their options are still open. On the other hand, the aspiration toward something else is prevalent with the today's active generations, but together with some precaution. The force to change the status of things is distributed. Most likely, it will be a world claiming multilateralism, a hectic world, but without clashes at the superpowers level, each knowing well that little is gained from such collisions.

\footnotetext{
${ }^{41}$ SUI, Yu - China in a Changing World. p. 309-312.
} 
The European Union will face the pressure of reorganization ${ }^{42}$. The fact is that, without a profound reorganization in the direction of democratization, the fate of the European Union will be jeopardized.

A chorus accompanies the last decade of geopolitical reflections: if after 1989, the United Europe was at the forefront, today, it seems to have passed in the second line of interests with the world leaders.

A figure such as the former Chancellor Helmut Schmidt ${ }^{43}$ pointed to the fact that without a foreign and defense policy, the European Union cannot play a major international role. The European Union has not achieved the objective of the "Lisbon strategy" to become the most competitive organization in the world, and, consequently, it has nothing else to do but follow the cycles of the world economy ${ }^{44}$. In fact, Europe has lost its primacy in education and has much to do to be able to compete with the United States. In Europe, the danger is not the recession, but a "recession without end" ${ }^{45}$, which has its source in an enormous public debt, to which no solution has been found. Asia has become the "pivot" of American policy ${ }^{46}$ and it remains so.

The European presence in the world is not only a matter of opinion, but also of action. For example, the "Arab spring" has surprised the European authorities unaware of what was going on in Tunis, Tripoli or Cairo. "The Syrian Conflict" has shown incapacity to find a way out it. "The Ukrainian Crisis" has been poorly managed, so that, even today, a solution is not in sight. There is no courage to face the reality of the Middle East, with the threats of some small groups who find access to the most sophisticated weapons and who manifestly distort history. The European participation in Africa is mainly reactive, after years in which the press in African capitals accused European NGOs of bias. Not to mention Southeast Asia or South America, where Europe comes after others have already taken the initiative.

However, the truth is that the European Union has lost its relevance not only for reasons of foreign policy and defense, but also because of the "stagnation" in which its inner policy has entered. Before getting a new weight abroad, the European Union needs internal change, a reorganization towards democratization.

What is this all about? European analyses of the present European societies advance alarming diagnosis. Unfortunately, an institutional formalism has penetrated the European Union. It's not because the institutions would be inappropriate, but because,

\footnotetext{
${ }^{42}$ See BITTNER, Jochen - So nicht Europa! Die drei grossen Fehler der EU Deutscher München: Taschenbuch Verlag, 2010; MARGA, Andrei - The Destiny of Europe. București: Editura Academiei Române, 2012; GIDDENS, Anthony - Turbulent and Mighty Continent. What Future for Europe?. Cambridge: Polity Press, 2014; SIMMS, Brandan; ZEEB, Benjamin - Europe am Abgrund. Plädoyer für die Vereinigen Staaten von Europe. München: C.H.Beck, 2016.

${ }^{43}$ SCHMIDT, Helmut - Die Mächte der Zukunft. Gewinner und Verlierer in der Welt von morgen. München: Goldmann, 2006. p. 187.

${ }^{44}$ GREENSPAN, Alan - L'Era della turbolenza. Milano: Sperling \& Kupfer, 2005.

${ }^{45}$ KAROUI, Hakim El - Reinventer l'Occident. Essai sur une crise economique et culturelle. Paris: Flammarion, 2010.

${ }^{46}$ CLINTON, Hillary - Hard Choices. New York: Simon and Schuster, 2014.
} 
in the last decade, too few were still interested in the substance of things, namely, in the space of positive affirmation of citizens. In fact, faced with this situation, "the left" has remained perplexed, while "the right" views are of short breath ${ }^{47}$. Political controversy is thus too distanced from the needs of the citizens of Europe.

In any case, Europe's vulnerability is not the "way of life" provided by social security policies ${ }^{48}$. The problem is the inclusive capacity and the productivity of the United Europe, which cannot be solved without institutional reforms and a new commitment of the Europeans themselves. These conditions can be met, however, only through a movement from within. Only if the Europeans regain the 1989 enthusiasm and motivation, will they be able to bring about the moral, the civic and the political engagement without which the today's problems cannot be solved.

We may, of course, regard the European Union's foreign policy from various angles, but the fact remains that extension at the expense of integration is not productive, and it may even endanger the entire construction. Three concrete issues will have to be discussed and dealt with in the European Union from a fresh perspective: bureaucracy, staff qualification and election issues.

The volume reached by bureaucracy in the European Union entitles us to ask: isn't bureaucracy the problem par excellence of the European Union, rather than the "social State", as the hastily improvised right thinks in the last decade? Isn't it a fact that large resources of the European Union are swallowed by an invading bureaucracy which wants to keep its positions?

Some crucial debates about the situation of the world are currently carried out in Europe, but authorities are not interested in them ${ }^{49}$. European decisions are taken by ignoring these debates. Policy is understood as the fight of persons and parties for positions, rather than the starting up of community projects. The politician is seen more as an actor in a Darwinian selection, than as a servant of the public interest. What is worse, with some notable exceptions, the representatives in Brussels of the different European countries are selected without a serious competition and their competence is questionable. There are signs, as important European thinkers have foreseen, that the institutionalized European elite has no longer a professional and civic breadth, and it blurs the scene by spreading the impression that there are no alternatives.

In the European Union, free elections are carried out based on democratic procedures. But what comes out, at the end of the application of all procedures, is not satisfying so far: Europe loses in global relevance. The difficulties of financial and economic management, the insufficient innovation, and motivation crises overwhelm it, and, more and more, people being disappointed, retire into private life. Apathy becomes burdensome in an era in which general competitiveness and, finally, safety depend on the participation of the majority of citizens. Consequently, the way in which elections are understood should be put into question.

\footnotetext{
${ }^{47}$ NASSEHI, Armin-Die letzte Stunde der Wahrheit. Warum rechts und links sind keine Alternative mehr und Gesellschaft ganz anders beschrieben werden muss. Hamburg: Murmann, 2015. p. 66.

${ }^{48}$ As Zbigniew Brzezinski hastily accused in his Strategic Vision. America and the Crisis of Global Power, Basic Books, New York 2012, p. 22.

${ }^{49}$ JUDT, Tony - Postwar. A History of Europe since 1945. New York: Penguin, 2005, p. 796
} 
Elections are not only about the selection representatives who are later not to be disturbed, as a wrong impression was induced. Not only the "functional significance", but also of the "deliberative significance" of the vote should be a concern for democrats, in order to turn the elections into something more than a ritual. Only in this way the circle of decidents, which already has the tendency to close itself, can receive oxygen, and the unfortunate apathy surrounding it will decrease. The global relevance of Europe depends on the vitality of its democracy, but democracy is only vigorous when the voter is assured that political will includes his/her vote.

Today, we live in a world of turmoil, which Hegel had broadly anticipated. Now, nearly two hundred years ago, in The History of Philosophy Lectures, the philosopher was speaking of the "aggitation and difficulties” that will accompany the future, and he would consider them to be the result of a change of „legitimation” toward legitimation through the will of the people. At present, there are several factors that are fueling this continuous movement: technologies, modern science, religious orientations, the „great politics” anticipated by Nietzsche, and, of course, the legitimation efforts.

Can we still formulate generalizations with claims of infallibility, as before? I think we can realistically advance modelings.

For example, in an era of unprecedented socialisation, the meaning of life is, with each of us, inevitably dependent on the evolution of the society in which we live. Different societies depend on outside interactions. How can you keep the rigor of ethics in a society with considerable corruption? How can a State be democratized as long as it lacks culture? How to have advanced economy and justice with unqualified leaders? How to remain independent in the era of great concentration of power? What impact does culture still have in the context of in force emergency actions? How effective can be ethics in a competition economy? Such questions will dominate the scene, and they can be answered only with alternative modelings of development or solutions.

Modeling is important, because it can tell us more through the answers to such questions, than a brief generalization. In any case, from modelings we can draw a series of consequences. Here are some of them.

A first consequence is the widening of the perspective. History did not stop with the German Reich, with the victory of Communism, or wih neoliberalism. History does not end because, whatever the resistance, the solutions of an open future will prevail, not those of the past.

The second consequence is the strengthening of the autonomy of science, philosophy, religion, but also of the need of connecting them. Each will need the others. Philosophy needs an upgrade with the problems coming from science and religion, knowing well that, for instance, the Greek theme of a "good life” and the Jewish „theme of salvation" have fueled it until today. Religion needs the conjunction with philosophy and science in order not to become irrelevant. Science cannot isolate itself from the other two without becoming irrational.

The third consequence is the emergence of opportunities for new visions. Schönberg said that, in a musical piece, the idea is more important than the style, and, today, 
we cannot but give him justice. It's all about the idea arising from the finding of oneself. "Mon jeu est a moi", Constantin Brâncuşi said"50, giving us the key to position ourselves in front of the world.

The fourth consequence consists of updating the "philosophy of public life" in a world where everyone's life depends on decisions to be taken within the institutions. We don't have to wait for solutions from providential leaders, from subjects in larger format, from any foreign assistance, or from someone else. Nowhere in the world can somebody replace what the citizens themselves must do in a democratic way. Democracy has been thought up to now for the relatively small populations. It is time to elaborate democracy for larger populations.

How do these developments affect us? For Hegel, history was "a progress in the consciousness of freedom" and, hence, to freedom. Today, we have this advancement, but we don't have the extension of freedom. Max Weber has left us an anticipation in the terrifying image of the "case of obedience as strong as steel". We live under multiple dependencies, but we don't have only the obligation of obedience. Marcuse spoke of the "one-dimensional society", in which the possible is absorbed by the existing. We are faced with such an absorption, but the dimensions are still varied. My diagnosis ${ }^{51}$ is that we live in a world full of alternative developments, and with varied opportunities, but more uncertain.

To put it in an intuitive way, I would say that, very often, existing certainties have been lost. As a matter of fact, Leibniz' certainty that we live in the best of the possible worlds was ruined by the Lisbon earthquake (1755). The certainty of the thinkers of the Enlightenment that people act in an essentially rational way was ruled out by the First World War. The certainty that the market economy will be a sufficient economic framework was vanished by the 1929 and 2008 crises. Adam Smith's belief that that free people will take wise decisions have been contradicted by the still unsuccessful transitions to democracy. The certainty that democracies bring peace to societies has been questioned by the bent of democracies into dictatorship, in the 1930s. The conviction that people would not take other people's lives in their struggles and become beasts was refuted in Auschwitz. The certainty that, after 1989, the world is heading towards societies of freedom and democracy is circumstantiated every day now. The certainty that the good triumphs in any case has been shaken by the proliferation of nuclear weapons ${ }^{52}$. And these are just a few examples.

Uncertainty is not a reason for pessimism. The present uncertainty may be surpassed, not with comfortable ideas, but with a deeper inquiry into realities. This inquiry is a challenge, but also a historical chance for today's thinkers. A time of creativity, of new approaches and ideas has already come.

\footnotetext{
${ }^{50}$ GEORGESCU-GORJAN, Sorana - Așa grăit-a Brâncuşi. Ainsi parlait Brâncuși. Thus spoke Brâncuși. Bucharest: Scrisul Românesc, 2011.p. 143

${ }^{51}$ MARGA, Andrei - Societatea nesigură. București: Niculescu, 2016. p. 108-124

${ }^{52}$ See LUHMANN, Niklas - Die Gesellschaft der Gesellschaft. Frankfurt am Main: Suhrkamp, 1998; MAALOUF, Amin - Le Déreglement du monde. Paris: Grasset, 2009; MASALA, Carlo - Welt-Unordnung. Die globalen Krisen und das Versagen des Westens. München: C.H.Beck, 2016; MARGA, Andrei - Ordinea viitoare a lumii. Bucuresti: Niculescu, 2017, which capture the uncertainities of the present world.
} 


\section{References}

AIKMAN, David - Jesus in Beijing. How Christianity Is Transforming China and Changing the Global Balance of Power. Washington DC: Regnery Publishing, 2006. p. 282-294.

ANGANG, Hu - China in 2020. A New Type of Superpower. Washington DC: Brookings Institution Press, 2011. p. 95-120.

ATKINSON, Anthony B. - Inequality. What can be done?. Harvard University Press, 2015.

BAECKER, Dirk - Studien zur nächsten Gesellschaft. Frankfurt am Main: Suhrkamp, 2007. p. 7.

BELL, Daniel A. - China and Democracy. What America's flawed democracy could learn from China's one-party rule, in "Christian Science Monitor". (December, 24, 2012).

BERMAN, Harold - Recht und Rechtsrevolution: die Bildung der westlichen Rechtstradition, Frankfurt am Main: Suhrkamp, 1991.

BITTNER, Jochen - So nicht Europa! Die drei grossen Fehler der EU Deutscher München: Taschenbuch Verlag, 2010.

BOBBIO, Norberto - Il futuro della democrazia. Torino: Einaudi, 1995.

BRZEZINSKI, Zbigniew - Strategic Vision. America and the Crisis of Global Power, Basic Books, New York 2012, p. 22.

CHAYES, Sarah - Thieves of State. Why Corruption Threatens Global Security. New York, London: W.W.Norton \& Company, 2015.

CLINTON, Hillary - Hard Choices. New York: Simon and Schuster, 2014.

CROUCH, Colin- Postdemokratie. Frankfurt am Main: Suhrkamp, 2003. p. 30.

DEWEY, John - The Ethic of Democracy. 1898. In DEWEY, John - The Early Works 1882-1898. Illinois University Press, 1969.

FERGUSSON, Nial - Civilization. The West and the Rest. Allen Lane, 2011. p. 277-288.

GALBRAITH, James K. - Wachstum neu Denken. Was die Wirtschaft aus der Krise lernen muss?, Zürich: Rotpunkt Verlag: 2016.

GEORGESCU-GORJAN, Sorana - Așa grăit-a Brâncuși. Ainsi parlait Brâncuși. Thus spoke Brâncuși. Bucharest: Scrisul Românesc, 2011. p. 143

GIDDENS, Anthony - Turbulent and Mighty Continent. What Future for Europe?. Cambridge: Polity Press, 2014.

GILBERT, Paul- The Compassionate Mind. A New Approach to Life's Challenges. New York: New Harbinger, 2009.

GREENSPAN, Alan - L'Era della turbolenza. Milano: Sperling \& Kupfer, 2005.

HALPER, Stefan - The Beijing Consensus. How China's Authoritarian Model Will Dominate the Twenty-First Century. New York: Basic Books, 2010.

HUBER, Johannes- Länger leben.Medizinische Perspektiven und ihre Bedeutung für Gesellschaft. In LIESSMANN, Konrad Paul - Ruhm, Tod und Unsterblichkeit. Über der Umgang mit der Endlichkeit. Wien: Zsolnay, 2004.

JIE, Liu - Human Rights. China's Road. Beijing: China International Press, 2014.

JUDT, Tony - Postwar. A History of Europe since 1945. New York: Penguin, 2005, p. 796

KAROUI, Hakim El - Reinventer l'Occident. Essai sur une crise economique et culturelle. Paris: Flammarion, 2010. 
KEPING, Yu - How to Achieve Orderly Democracy, in "Beijing News". (July 13, 2014).

KRUGMAN, Paul - The Return of Depression Economics and the Crisis of 2008. New York; London: W.W.Norton \& Company, 2009.

LIESSMANN, Konrad Paul - Theorie der Unbildung. Die Irrtümer der Wissensgesellschaft. München, Zürich: Piper, 2008.

LUHMANN, Niklas - Die Gesellschaft der Gesellschaft. Frankfurt am Main: Suhrkamp, 1998. MAALOUF, Amin - Le Déreglement du monde. Paris: Grasset, 2009.

MANNENT, Pierre- La raison des nations. Reflexions sut la démocratie en Europe. Paris: Gallimard, 2006.

MARGA, Andrei - Ascensiunea globală a Chinei. București: Niculescu, 2015.

MARGA, Andrei - Guvernanță și guvernare. Un viraj al democrației?. București: Compania, 2013. p.62-121.

MARGA, Andrei - Metanarativii actuali. Modernizare, dezvoltare, globalizare. Cluj-Napoca: Gând Transilvan, 2015. p. 131-182.

MARGA, Andrei - Ordinea viitoare a lumii. București: Niculescu, 2017.

MARGA, Andrei- Societatea nesigură. București: Niculescu, 2016. p. 108-124.

MARGA, Andrei - The Destiny of Europe. București: Editura Academiei Române, 2012.

MARX, Reinhardt Cardinal - Das Kapital. Ein Plädoyer für den Menschen. München: Knaur, 2010. p.159-187.

MASALA, Carlo - Welt-Unordnung. Die globalen Krisen und das Versagen des Westens. München: C.H.Beck, 2016.

MATURANA, Humberto R. - Kognition. In SCHMIDT, Siegfried J. - Der Diskurs des Radikalen Konstructivismus. Frankfurt am Main: Suhrkamp, 1987. p.89-118.

MORGAN, Glyn - The Idea of an European Super State: Public Justification and European Integration. Princeton University Press. 2007. p. 199-205.

MÜNCH, Richard - Globale Eliten, locale Authoritäten. Frankfurt am Main: Suhrkamp, 2009.

MYERS, Steven Lee - Putin - der neue Tsar. Seine Politik - Sein Russland. Zürich: Orel Füssli, 2016. p. 232, 424.

NALBANDOV, Robert - Russian Foreign Policy under Putin. Not by Bread Alone. Potomac Books, The University of Nebraska Press, 2016.

NASSEHI, Armin - Die letzte Stunde der Wahrheit. Warum rechts und links sind keine Alternative mehr und Gesellschaft ganz anders beschrieben werden muss. Hamburg: Murmann, 2015. p. 66.

NEIMAN, Susan - Das Böse denken? Eine andere Geschichte der Philosophie. Frankfurt am Main: Suhrkamp, 2006.

NIDA-RÜMELIN, Julian; ZIERER, Klaus - Auf dem Weg in eine neue deutsche Bildungskatastrophe. Zwölf unangenehme Wahrheiten. Freiburg im Breisgau: Herder, 2015, p. 93-154.

NYE, Joseph S. - Is the American Century Over?. Cambridge: Polity Press, 2015.

O'DONNELL, Guillermo; SCHMITTER, Philippe C.- Transitions from Authoritarian Rule. Tentative Conclusions about Uncertain Democracies. Baltimore: The John Hopkins University Press, 1986.

PIKETTY, Thomas - Chronicles. On our troubled times. New York: Viking, 2016. 
RATZINGER, Joseph / Benedikt XVII - Jesus von Nazareth. Herder, Freiburg, Basel, Wien, Band 1, 2007. p. 15-22.

SACHS, Jeffrey D. - The fine della poverta. Comme i paesi potrebbero defitivamente eliminare miseria dal pianetta. Milano: Mondadori, 2005. p. 140-157.

SAKWA, Richard - Putin. Russia's Choice. London: Routledge, 2008. Part 3.

SASSEN, Saskia - Territory - Authority - Rights. From Medieval to Global Assemblages. Princeton University Press, 2006.

SCHMIDT, Eric; COHEN, Jarel - The New Digital Era. Reshaping the Future of People, Nations and Business. London: John Murray, 2014.

SCHMIDT, Helmut - Die Mächte der Zukunft. Gewinner und Verlierer in der Welt von morgen. München: Goldmann, 2006. p. 187.

SIMMS, Brandan; ZEEB, Benjamin - Europe am Abgrund. Plädoyer für die Vereinigen Staaten von Europe. München: C.H.Beck, 2016.

SMOLIN, Lee - Time Reborn. From the Crisis in Physics to the Future of the Universe. Harcourt: Houghton Mifflin, 2013. Part I, 5.

STIGLITZ, Joseph - La globalizzazione e suoi oppositori. Torino: Einaudi, 2002. p.224.

STIGLITZ, Joseph E.- The Great Divide. New York: Penguin, 2015.

SUI, Yu - China in a Changing World. Beijing: Foreign Languages Press, 2015.

TROUT, J.D. - Why Empathy Matters. The Science and Psychology of Better Judgement. New York: Penguin, 2008. p.21-55.

WEIZSÄCKER, Carl von - Die Einheit der Natur. München: Carl Hanser, 1971.

WILLKE, Helmut - Demokratie in Zeiten der Konfusion. Frankfurt am Main: Suhrkamp, 2014. p. $95-98$.

YOVEL, Yirmiahu - Dark Ridle: Hegel, Nietzsche and the Jews. Cambridge: Polity, 1996.

ZACHARIA, Fareed - The Post-American World. W.W.Norton \& Company, 2012. p. 207. 